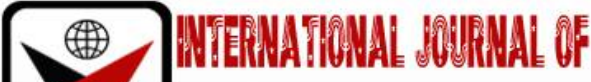

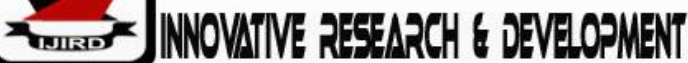

ISSN 2278-0211 (Online)

\section{INEC Improved Card Reader Machine and Credibility of the 2019 Gubernatorial Election in Rivers State, Nigeria}

\begin{tabular}{c}
\hline Anthony Chinonso Ajah \\
Self Employed, Department of Political Science, University of Nigeria, Nigeria \\
Tukura Nashuka Tino \\
Assistant Lecturer, Department of Political Science, Federal University, Nigeria \\
Merinoe Chukwudi Okiriaja \\
Civil Servant, Department of Political Science, University of Nigeria, Nigeria
\end{tabular}

\begin{abstract}
:
Information and Communication Technology (ICT) has become an increasingly and indispensable aspect of living and working in the $21^{\text {st }}$ century. Based on the assumption that an automated system through ICT can aid human efficiency and eliminate bias, INEC in 2015 fully adopted the use of CRM in the Nigerian elections. However, in its debut season, the CRM witnessed a lot of hitches in terms of functionality. Data from INEC shows that the machine recorded an underwhelming average success rate of 42\%nationwide during the presidential election. Therefore, to ensure a hitch-free election in 2019, INEC embarked on a massive repair and enhancement exercise to upgrade, fix, and improve all aspects of the CRM. Anchoring on the 'Cybernetics Model of Communications Theory', this paper examines the use of INEC improved CRM and the credibility of the 2019 gubernatorial election in Rivers State. Methodologically, a triangulation research design was utilized to facilitate the validation of data through qualitative and quantitative data collections. In the quantitative phase, 200 copies of questionnaires were randomly distributed in Port Harcourt, Obio-Akpor, Oyigbo, and Eleme local governments. Data collected were analyzed using Mean and Standard Deviation for the research items. Thus, items that rated 2.50 and above were considered as required while items that rated below 2.50 were considered not required. The paper found that the CRM was not given a fair trial and was not used in several places where results were produced due to heavy militarization of the election, and the destruction and hijacking of sensitive materials by cult groups, military personnel and armed thugs working for politicians. On the strength of the findings, the paper strongly recommended the adoption of an electronic voters' system where voters can log-in and vote using bank verification number (BVN) and personal identification number (PIN), and those with no such capacity can as well vote in an INEC designated area closer to them.
\end{abstract}

Keywords: Improved card reader machine, independent national electoral commission, election credibility, rivers state, gubernatorial election

\section{Introduction}

Information and Communication Technology (ICT) has become an increasingly and indispensable aspect of living and working in the $21^{\text {st }}$ century. Founded on the important role technology plays; institutes, governments, and individuals at all levels have continued to integrate and deploy it as a working tool to improve efficiency, eliminate fraud, increase productivity, enhance service delivery, among others (Adamu, 2017). Based on the assumption that ICT, if effectively used can ensure credibility by eliminating every form of irregularity in the electoral process, this paper investigates the impact of INEC improved Card Reader Machine (CRM) on the 2019 gubernatorial election in Rivers State.

In democratic governance, election represents the universally accepted process of legitimizing a government. Democracy also represents competitive politics, adherence to rule of law, human rights and freedom, and strict adherent to internal party democracy (Beetseh and Akpoo, 2015; Ayinde and Idowu 2016; Adamu, 2017; Bratton, 2008).However, recent studies have shown that elections in Nigeria; especially since the return to democracy in 1999 has not adhered strictly to these democratic principles. Elections have rather, been replete with irregularities such as electoral violence, over-voting, snatching of ballot boxes, underage voting, thuggery, manipulations of the voters' list, falsification of election results, use of security agencies against political opponents, and the intimidation of voters, among others (Ayinde and Idowu, 2016). Therefore, to get rid of these, and improve the Nigerian electoral system, the Independent National Electoral Commission (INEC) introduced the CRM into the electoral system in 2015 (Jega, 2015).

The CRM, an electronic device that uses highly secured cryptographic technology was configured to identify, verify, and authenticate the electorates' eligibility using the Permanent Voters Card (PVC) in a process generally called accreditation (INEC Manual, 2015). The CRM was deployed to all the 36 states of the federation during the 2015 and 2019 general elections as an anti-fraud device. The functions of the CRM are to identify eligible voters, eliminate over-voting, 
and data storage of election results in the polling unit (INEC, 2019 and Nwafor, 2019). However, despite the promise, and overwhelming enthusiasm that greeted the arrival of the CRM in 2015, several reports and live feeds indicate incidents of over-voting, underage voting, multiple thumb printing, thuggery, and violence, among others, especially in Rivers, Kano, Delta, Kogi, and Imo state during the 2015 and 2019 elections. For example, Nnochiri (2016), observed this:

INEC argued as a witness during the election petition tribunal hearing between Dr, Dakuku Peterside of the All Progressive Party (APC) and Chief NyesomWike of the People Democratic Party (PDP) that the total number of voters accredited with the CRM during the 2015 governorship election in Rivers State was 293, 072. This came against over 1.1 million votes cast during the poll (Nnochiri, 2016, P. 3).

Collaborating this, Uzodike and Onapajo (2019) observe that in Rivers State the PDP gubernatorial candidate was awarded 1,029,102 votes against the official number of accredited voters $(292,878)$. Despite the use of CRM cases of overvoting was recorded in several polling units across Nigeria. In a similar report, Niger-Delta Situation Room (2016) reports observing incidents of over-voting, result-sheet mutilation during the 2015 elections. The challenges that confronted the CRM in the 2015 poll are not limited to over-voting. Nwafor (2019) laments that, among other challenges, the 2015 elections witnessed a high rate of failed fingerprints authentication (57.3\%).

However, literature suggests that the 2015 elections performed relatively better than previous elections in Nigeria. First, it was keenly contested with the coalition of political parties (ACN, CPC, and ANPP, among others) mounting a formidable opposition against the ruling party (PDP). Secondly, the 2015 elections witnessed minimal post-electoral violence and litigation with losers congratulating the winners in unprecedented gestures that show acceptability of the poll (Yakubu, 2017; Ayen and Esan, 2018; Kalyani, 2017). Based on these achievements, there was much optimism that the next election (2019) will consolidate on the success of 2015 to bring the much-needed credible poll in Nigeria.

The 2019 elections were held on February $26^{\text {th }}$ and March $9^{\text {th }}$, respectively, but unlike the 2015 elections which analysts praised as one of the best in recent times, even against its shortcoming, the 2019 election was described as a disgrace (US Institute of Peace, 2019; Niger-Delta Watch, 2019; CLEEN Foundation, 2019). At the center of the alleged shameful display was the Rivers State governorship election (Niger-Delta Watch, 2019). The CLEEN Foundation (2019) report contends that the 2019 governorship election in Rivers States is one of the most militarized, controversial, and violent riddled elections in Nigeria. During the exercise, YIAGA Africa (2019) and other election observers including Civil Liberty Organizations - (Situation Room, Niger-Delta Watch, CSSR) reports show evidence of gang-up between uniformed and military personnel working for politicians to compromise the process; deliberate destruction and snatching of voting materials. Niger-Delta Watch (2019) observes that the climax of the controversy that engulfed the 2019 governorship election in Rivers State was the un-ceremonial suspension of the result collation process after 17 local governments out of 23 had been announced. The election was thus declared inconclusive on the ground of widespread violence. Following the suspension, INEC has to address the public through a press release and insisted that such a measure was necessary due to widespread violence and alleged military interference with the election. Also, on the eve of this announcement, a PDP collation agent in Khana local government, Dr. Ferry Gberegbe, among others was reportedly killed in the collation center by the Nigerian security agencies (NDI, 2019 and Niger-Delta Watch, 2019).

In view of this, the paper seeks to validate or reject the hypothesis which said that the use of INEC improved CRM in the 2019 gubernatorial election in Rivers failed to enhance the credibility of the election. By so doing, the study utilized both qualitative and quantitative data through content analysis of pertinent literature and the administration of questionnaires in Port Harcourt and Obio-Akpor local government areas. The paper was divided into four sections, following the in the introduction and literature review, section three deals with the theoretical analysis while the final phase includes the findings, conclusion, and recommendations

\subsection{Conceptual Clarification}

In this section, key concepts as was used in this study were defined.

\subsubsection{Card Reader Machine}

The Card Reader Machine (CRM)'is an electronic device designed on RFID technology used primarily for reading PVCs issued by INEC. CRM has both software and hardware components. The software on the CRM that use for voter authentication is called IVAS, (i.e. INEC Voters Authentication System)', (INEC Manual, 2019, p. 42). It is configured to verify, authenticate and accredit electorates permanent voters' cards (PVCs) in other to, ascertain whether voters' PVC was issued by INEC and to verify through biometric finger scanning the legitimate owner of the card. The card reader uses a highly secured cryptographic technology which is commonly used in devices that need to perform secure transactions such as pay terminals. It has an ultra-low power consumption rate with a single-core frequency of $1.2 \mathrm{GHz}$ and an Android 4.2.2 operating system (INEC Manual, 2019; Ibrahim and Makama, 2015; Akwen et al, 2018; Ituma, 2017).

\subsubsection{Permanent Voters Card}

The Permanent Voters Card (PVC) is a voters' card issued by the Nigerian electoral umpire, INEC. According to the INEC Manual (2019), it is the only form of identification for voting, and acknowledgment that the voter is duly registered to vote. It has the following information number of the polling unit, Voter's image, the Voter Identification Number, Delimitation, holder's Name, Date of birth, Gender, Occupation, Address, Barcode, QR code (2D containing the information of the VIN, delimitation, address), Card Serial Number, Last Name, VIN of the voter and Date of registration, Batch Number, and the voter fingerprints indicator (INEC Manual, 2019). 


\subsection{Independent National Electoral Commission}

The Independent National Electoral Commission (INEC) in this context is the electoral umpire that is responsible for the conduct of elections in Nigeria.

\subsubsection{Election}

This is the process by which citizen of a particular country selects their leaders. It is commonly used in democratic nations where representatives are elected at intervals to pilot the affair of their people.

\subsubsection{Credibility}

Credibility in this context implies reliability and the quality of being trusted and believed in. Election credibility, therefore, means an election that is free from malpractice, fair in competitiveness and reflects all levels of transparency in its processes.

\section{Literature Review}

The introduction of biometric technology into the Nigerian electoral system evolved over the years since 2011 . Akwen et' al (2018) observe that the first major step towards finding a technological solution to electoral malpractices in Nigeria was the introduction of 'Automated Fingerprint Identification System' (AFIS) by INEC during the 2011 general elections. This move was based on the assumption that 'trustworthy voter register and reliable tools for identification of eligible voters are some of the preconditions necessary for malpractices free elections in Nigeria'. Also, section (49) subsection (1) of the electoral amendment bill (2018) authorized the compulsory use of technology for voters' accreditation during an election (Akwen et' al, 2018 and Ituma, 2017).

Also, (Battaglia, Iannizzotto, and Bello, 2014; Yakubu, 2017; Kalyani, 2017; Shradha, and Chourasia, 2015; Gelb and Decker, 2012) argue that the use of technology in Nigeria elections is not new. Since 1999, the electoral system has evolved from the use of typewriters in 1999 to Direct Data Capture Machine (DDCM) in 2003, and Electronic Voters' Register (EVR) in 2007, to Biometric Voters Register (BVR) using the temporal voters' card (TVC) in 2011, and Biometric Smart Card Reader (BSCR) in 2015.

(Ayen and Esan, 2018; Jega, 2015) observe that since 2015, the deployment of the CRM has triggered a lot of debate and controversies among stakeholders, observers, and even the academic literature is replete with contending views on the impact of CRM on the Nigerian elections. Beetseh and Akpoo, (2015) in testing the hypothesis that says 'there is credibility in the use of Smart Card Reader (SCR) in Nigerians 2015 general Elections' argue that the SCR eliminated the possibility of invalid and multiple votes which, in many cases, are the root causes of controversies and election petitions. They also observe that the use of this technology has made the process much faster and accurate by eliminating the incident of over-voting. Similarly, Ituma (2017) agreed with Beetseh and Akpoo's view and asserts that the deployment of the SCR reduced electoral conflicts and violence to a minimal level in 2015 as the election was seen to be transparent and credible. The above literature found that the use of SCR significantly reduced post-election violence, excessive and pointless attacking, and degrading between the winners and losers.Nwangwu (2015), Alebiosu (2015), Iwuoha (2018) then added that the use of CRM has rekindled the confidence of Nigerian on the electoral process and ensure that the principle of 'one man one vote' is maintained.

However, another school of thought has come to criticize the performance of the CRM (Ojukwu, Mbah, and Maduekwe, 2019; Attoh, 2015; Ayinde and Idowu 2016; Nwafor, 2019; Chidubem, 2018), they argue that the Nigeria elections have continued to be marred by irregularities and electoral violence even after the introduction of the CRM in 2015. They pointed out that, for instance, in the 2015 general elections, the CRM performed poorly especially in capturing electorates fingerprints, with just a $43 \%$ success rate in the presidential election, the card reader failed to live up to expectation. Even more disappointing is that the use of CRM did not stop electoral violence and manipulation.

Although the literature is replete with issues associated with the use of CRM and election credibility in Nigeria, the impact of CRM on the 2019 gubernatorial election in Rivers State has so far received little or no attention. Also, existing literature has failed to explore whether the INEC improvement on the CRMbefore the 2019 election enhanced the credibility of the 2019 gubernatorial election in Rivers State. This is surprising given that Rivers remains one of the most strategic, but violence-prone states in Nigeria. Therefore, this paper substantially addressed this gap for both academic and public utility.

\section{Methodology}

This paper adopted the triangulation research design. By this design, the paper was able to use both qualitative and quantitative data to analyze and evaluate the impact of CRM in the 2019 gubernatorial Election in Rivers State. Triangulation design is a type of mixed-method research that facilitates the validation of data through cross-examination and verification of findings from more than one source. It tests the consistency of results obtained through different instruments and widening one's understanding of the issue under discussion (Kennedy and Patrick, 2009).

Data for the study were extracted from reports such as the CLEEN foundation reports on the conduct of the 2019 elections in the Niger-Delta; Niger-Delta Watch (2019); Situation Room Election Monitoring Report (2019); YIAGA Africa report, (2019); NBA Election Working Group Report, (2019); US Institute of Peace (2019); IRI/NDI final report (2019), and the EU Election Observers Mission final report (2019). Relevant academic journals, books, conference papers, theses, and dissertations were also utilized.

To hence understanding and support the results generated through secondary data, 200 copies of questionnaires were randomly distributed in Port Harcourt, Obio-Akpor, Oyigbo, and Eleme local governments. The choice of these four 
local governments out of the 26 local governments that made up the state is based on their proximity to one another and the lack of finance on the side of the researchers to travel further. Then, a structured 'Card Reader and Credibility of the 2019 Gubernatorial Election in Rivers State (CRACGERS) instrument was used for data collection. The instrument contained two sections, namely A and B. The section A contained personal data of respondents, while section B contained structured 10- items of the instrument. The instrument was modeled on a four-point scale of Strongly Disagree (SD), Disagree (D), Agreed (A), and Strongly Agreed (SA) with numerical values of 4, 3, 2, and 1 respectively. Data collected were analyzed using Mean and Standard Deviation for the research items. Thus, items that rated 2.50 and above were considered as required while items that rated below 2.50 were considered as not required.

Theoretically, the study adopted 'the Cybernetics Model of Communications Theory' (CMCT). Contemporary cybernetics began as an interdisciplinary study connecting the fields of communication, control systems, logic modeling, evolutionary biology, and politics (Wiener, 1948; Mcculloch, 1969; Rosenblueth, 1945; Ashby, 1956; Neumann, 1947; Deutsch, 1963). However, it was Wiener (1950) 'The Human Use of Human Beings: Cybernetics and Society' that first popularized the social implications of cybernetics by drawing analogies between automatic systems and human institutions, before Karl Deutsch's ground-breaking work became the first to formulate a fully developed theory of politics based on a communications model in his (1963) work 'Nerves of Government: Models of Political Communication and Control'.

CMCT assumes that a communication network is characterized by 'feedback mechanism'. By this, it means that input (command) is received, processed, and returned as output (result), and again, the output can be converted to input. Also, the theory assumes that the inflow or outflow of information from one end to another in the communication network is not automatic; there is a specific role of human beings called the co-coordinating process. This implies that human beings are the drivers of the cybernetic communication network, and without a human aide, the system may not produce the desired output.

\subsection{The Use of Card Reader Machine}

The CRM introduced by INEC in 2015 was the first time in the Nigeria election history that information and communication technological device was fully deployed. Although the 2011 election witnessed a partial use of Electronic Voters Register (EVR) through the Temporal Voters' Card (TVC), it was during the 2015 election year that the accreditation (identification, verification, and authentication) was done using technology. The device uses an encrypted communication system primarily used by financial institutions and payment terminals to perform transactions (INEC Manual, 2019). This implies that data in the system cannot be assessed by a third party without permission. The INEC technology can receive information (PVC, and Fingerprints) process them, and bring out the result as an output (verification of the PVC, and authentication of the fingerprint). Above all, the machine can record, store, and transmits the total number of voters accredited in a polling unit by adding the number of successful and failed authentications. The device was designed to store the identification number (VIN) of every PVC authenticated whether successful or not, and each PVC was configured to work in a particular polling unit with a designated CRM. Furthermore, CMCT assumes that the communication network is not automatic, meaning that human beings play a significant role in the coordination process. By implication, the CRM can only work or be effective if properly manned. This is because; the machine can neither operate itself nor ensure the credibility of an election if not diligently managed by trained INEC staff (INEC, 2019).

The theory has shown that the human factor is an indispensable variable when assessing the impact or performance of the CRM. That is to imply that basic human errors can even make the machine less effective. Furthermore, in a case where the machine is manipulated or compromised, CMCT contends that the expected result may not be achieved. In the use of the CRM, Nwafor (2019) argues that one of the challenges of the CRM in 2015 was the frequent failure to capture voters' fingerprints. An example of this scenario is when the device failed to capture the formal president, Dr. Goodluck Jonathan in his polling unit. According to Nwafor (2019), about 57\% of the total accreditations during the 2015 presidential election failed. This made INEC restore to the use of manual accreditation through the incident form. In the discussion, the issues and challenges of the CRM, Chidi Nwafor, the director of ICT, INEC Nigeria observes that:

The major issue observed with the 2015 VAS was a high rate of failed fingerprints authentication; The rate of successful fingerprint authentication in the 2015 Presidential Election was 42.7\%, which was considered quite low; " There were other challenges observed, which needed to be addressed before the 2019 General Elections - hence the enhancement of SCR project (Nwafor, 2019, p. 7)

Although the 2015 election was hailed by both local and international observers, the controversy caused by multiple failures of the CRM coupled with some human errors, battery problem, and the inability of some INEC ad-hoc staff to properly handle the device left much to be desired; hence INEC resolves to improve on the device before the 2019 elections.

\subsection{Enhancement of the CRM for the 2019 Elections}

Following the massive failure of the CRM to capture voters in the 2015 election and other associated problems, INEC promised a better election in 2019. To achieve this, they embarked on enhancement exercises to fix some of the faults identified in 2015. Table 1 summarized the areas and nature of improvement on the CRM 


\begin{tabular}{|c|c|c|}
\hline $\mathbf{S} / \mathbf{N}$ & New Features (Hardware) & Advantage \\
\hline 1 & $\begin{array}{l}\text { Inclusion of CMOS batteries in the new } \\
\text { CRMs }\end{array}$ & $\begin{array}{l}\text { To ensure that configured and BIOS settings are retained } \\
\text { and cannot be tampered with when batteries are removed. }\end{array}$ \\
\hline 2 & $\begin{array}{c}\text { Broader-surfaced fingerprints } \\
\text { Scanners }\end{array}$ & $\begin{array}{l}\text { For capturing a wider surface area of the finger to match } \\
\text { the referenced fingerprint template. It also increases the } \\
\text { rate of successful accreditation. }\end{array}$ \\
\hline 3 & Inclusion of SD cards in the CRMs & $\begin{array}{c}\text { Upgrade of the total memory size of the CRMs provided } \\
\text { additional space to store recaptured fingerprints and other } \\
\text { details of accredited voters. }\end{array}$ \\
\hline 4 & $\begin{array}{l}\text { Provision of tamper-proof seals to } \\
\text { battery compartments }\end{array}$ & $\begin{array}{l}\text { This tamper-proof seal seals off the battery compartments, } \\
\text { eliminating issues associated with the removal of CRM } \\
\text { battery. No one can open the battery compartment after the } \\
\text { configuration has been concluded. So, no one can alter the } \\
\text { CRM dates by removal of batteries. }\end{array}$ \\
\hline 5 & Replacement of SCR Batteries & $\begin{array}{c}\text { 4000MhA batteries were supplied to replace the existing } \\
\text { 3000MhA batteries - giving the CRMs longer hours of } \\
\text { operations }\end{array}$ \\
\hline $\mathbf{S} / \mathbf{N}$ & New Features (Software) & Advantage \\
\hline 1 & $\begin{array}{l}\text { The CRM application can nowread the } \\
\text { IMEI (International Mobile Station } \\
\text { Equipment Identity) number and link } \\
\text { each IMEI to a particular PU }\end{array}$ & $\begin{array}{l}\text { This made it easier to identify CRMs that have not been } \\
\text { configured and those with data not yet uploaded }\end{array}$ \\
\hline 2 & $\begin{array}{l}\text { The Resetting button can now be } \\
\text { prompt multiple times for data upload } \\
\text { verification before purging the } \\
\text { database. }\end{array}$ & $\begin{array}{c}\text { This made it important for technical staff, who wish to } \\
\text { purge the SCR, to first upload the accreditation data before } \\
\text { purging. }\end{array}$ \\
\hline 3 & $\begin{array}{l}\text { Removal of manual settings of dates } \\
\text { and times. This means that date } \\
\text { settings can only be possible by } \\
\text { connecting the readers to a network - } \\
\text { either wireless or GSM network } \\
\text { providers }\end{array}$ & $\begin{array}{l}\text { This eliminated cases of changing of date and time of the } \\
\text { SCR to a date set for election to take place, so that false } \\
\text { accreditations can be made to happen, and data stored on } \\
\text { the SCRs before election day }\end{array}$ \\
\hline 4 & $\begin{array}{l}\text { In the event of failed authentication, } \\
\text { the SCR will immediately capture the } \\
\text { voter fingerprints, provided his/her } \\
\text { name appears in the PDF printed voter } \\
\text { register of that particular polling } \\
\text { station }\end{array}$ & $\begin{array}{l}\text { This eliminated the use of incident forms and further } \\
\text { improves the database of voters' fingerprints. It reduces the } \\
\text { total number of voters with failed accreditation }\end{array}$ \\
\hline 5 & $\begin{array}{l}\text { When the close accreditation process is } \\
\text { initiated by the user, the software } \\
\text { should prompt for user password }\end{array}$ & $\begin{array}{l}\text { This prevented incidences of the unintentional close of } \\
\text { accreditation, preventing further voter accreditation until a } \\
\text { technical support staff is called to open the closed software }\end{array}$ \\
\hline 6 & $\begin{array}{l}\text { The SCR can now detect any available } \\
\text { Wi-Fi and prompt the user for a } \\
\text { password without having to get into } \\
\text { the system settings }\end{array}$ & $\begin{array}{l}\text { When the date on a CRM is wrong, the user can now switch } \\
\text { on the WIFI and connect to any available hotspot and } \\
\text { download the correct data and time. This used to be a major } \\
\text { issue as only technical support staff could do this }\end{array}$ \\
\hline
\end{tabular}

As identified in table 1, INEC made a concrete effort to ensure that the 2019 election was hitches free. First, the accreditation system was improved to ensure that voters whose accreditation data were not uploaded after the elections were easily identified. The connectivity of the device to detect Wi-Fi was made to be easily carried out by poll officials instead of waiting for technical support. The enhancements improved the Fingerprints capturing and matching process due to thewider fingerprint Scanner surface which now made it faster to authenticate (Nwafor, 2019).

Despite this improvement, reports indicate that the CRM was not used in several polling units in Rivers State. In the March $9^{\text {th }}$ poll, Situation Room reports showed that voting failed to start even around 11: am in Gokana, Onelga, Obio/Akpor, Khana, Ogu/Bolo, Ikwere, and other local government areas. There were reports of men in military uniform moving from polling units to polling in Ikwere local government bounding INEC staff and the CRM to an unknown destination. In other cases, INEC officials were forced to alter the results in the polling unit (SLO, 2019; Niger Delta Watch, 2019).

\subsection{The Credibility of the 2019 Gubernatorial Election in River State}

Although serious overhaul was carried out to improve the performance of the CRM, the 2019 election failed to meet up with expectations (Niger Delta Watch, 2019). YIAGA Africa report, (2019) argues that one of the most underwhelming 
and less credible elections in 2019 was the March 9th, governorship election in Rivers State. Despite the huge resources and preparation by the electoral umpire, the outcome of the 2019 elections was relatively underwhelming. Collaborating this, the Situation Room Report (2019) observes that the election started amidst tension, highly militarized environment, rhetoric and personality clash between the camp of the incumbent governor who was also the candidate of the PDP, and his predecessor and Minister of transportation, chief Rotimi Chibuike Amaechi, a chieftain of the APC (US Institute of Peace, 2019). Reports suggest that during the election, armed thugs had a field day invading polling units and intimidating voters (IRI/NDI, 2019). Also, there was a strong allegation of a gang-up between the military and some politicians to manipulate the election outcome. Similarly, the Niger-Delta Watch (2019) final report on the conduct of the 2019 elections in Rivers State indicates to have received nearly 200 incident reports submitted by citizen election observers as part of Niger Delta Watch Civil Society Election Monitoring Program. In those reports, the observers identified the following key issues:

- Deliberate destruction and snatching of voting materials, this included trucks carrying sensitive electoral materials being set ablaze and voting cards taken from polling stations to other places for illegal thumb printing.

- Violence targeting voters, security agents, and the INEC staff, in particular, including Ad-hoc staff in several polling units who came under pressure to change results.

- Gang-up between uniformed and military personnel to compromise the process even in the collation centers.

- Use of armed gangs - including cult groups that are widely believed to be funded by politicians

Though these reports show that many lives were lost before and during the election, the most shocking remained the killing of a PDP collation officer in Khana local government, Dr. Ferry Gberegbe; a KenPolyBori lecturer at the collation center by the Nigeria security agents. The intractable nature of this crisis forced INEC to suspend the collation of results and declared the election inconclusive (Niger- Delta Watch, 2019).

In this paper, primary data generated through our questionnaire survey was used to support the reports extracted from the literature. In examining whether the use of the INEC improved CRM enhanced the credibility of the 2019 gubernatorial election in Rivers State, 200 copies of questionnaires were randomly distributed in Port Harcourt and ObioAkpor local government areas. Using the Statistical Package for the Social Sciences (SPSS), the Mean of the respondents' responses were summarized in table 2 and the hypothesis tested at a 0.5 level of significance.

\begin{tabular}{|c|c|c|c|c|c|}
\hline $\mathbf{S} / \mathbf{N}$ & Item Statements & $\mathbf{N}$ & Mean & S.D & Decision \\
\hline 1 & $\begin{array}{l}\text { The CRM made the } 2019 \text { governorship poll in Rivers State } \\
\text { peaceful, transparent and credible }\end{array}$ & 379 & 2.15 & 1.11 & Disagreed \\
\hline 2 & $\begin{array}{l}\text { Enhancement of the CRM made electoral violence, } \\
\text { thuggery, and disruption of the balloting process less } \\
\text { influential to the election outcome }\end{array}$ & 379 & 1.99 & 1.23 & Disagreed \\
\hline 3 & $\begin{array}{c}\text { The improved CRM made accreditation and authentication } \\
\text { of voters faster and successful than in the previous } \\
\text { elections }\end{array}$ & 379 & 2.96 & .98 & Agreed \\
\hline 4 & $\begin{array}{c}\text { The use of the CRM reduced incidents of illegal thumb } \\
\text { printing and over voting }\end{array}$ & 379 & 2.09 & 1.15 & Disagreed \\
\hline 5 & $\begin{array}{l}\text { The card reader made it impossible for people to vote in } \\
\text { polling units other than where they were registered }\end{array}$ & 379 & 2.89 & .80 & Agreed \\
\hline 6 & $\begin{array}{l}\text { The use of CRM helped to ensure one man one vote during } \\
\text { the election }\end{array}$ & 379 & 2.80 & .81 & Agreed \\
\hline 7 & $\begin{array}{l}\text { The use of the CRM made the process open and devoid of } \\
\text { Electoral violence and intimidation }\end{array}$ & 379 & 1.91 & 1.11 & Disagreed \\
\hline 8 & $\begin{array}{c}\text { With the CRM, electorates' confidence and optimism in the } \\
\text { system that their votes will count has been restored }\end{array}$ & 379 & 1.93 & 1.08 & Disagreed \\
\hline 9 & $\begin{array}{l}\text { with the CRM, results collated in the polling units cannot be } \\
\text { changed in the collation center }\end{array}$ & 379 & 1.78 & .98 & Disagreed \\
\hline 10 & $\begin{array}{l}\text { The card reader machine prevented the falsification of the } \\
2019 \text { gubernatorial election results in Rivers State }\end{array}$ & 379 & 1.83 & 1.00 & Disagreed \\
\hline & Cluster & 379 & 2.21 & .318 & Disagreed \\
\hline
\end{tabular}

Table 2: Use of INEC Improved CRM Enhanced the Credibility of the 2019

Gubernatorial Election in Rivers State Source: Fieldwork 2019

The result in Table 2 shows the Mean and Standard Deviation of respondents regarding the use of CRM and the credibility of the 2019 gubernatorial election in Rivers State. Findings show the followings: the CRM failed to make the 2019 governorship poll in Rivers State peaceful, transparent and credible $(M=2.15, S D=1.11)$, the enhancement of the CRM could not make electoral violence, thuggery, and disruption of the balloting process less influential to the election outcome $(M=1.99, S D=1.23)$. However, the result shows the improvement on the CRM made accreditation and authentication of voters faster and successful than in the previous elections $(M=2.96, S D=.98)$, but the respondents' responses disagreed that the use of the CRM reduced incidents of illegal thumb-printing and over-voting during the 
exercise $(M=2.09, S D=1.15)$. Also, results support the assumption that the improved CRM made it impossible for people to vote in polling units other than where they were registered( $\mathrm{M}=2.89, \mathrm{SD}=.80)$.It equally agreed that the CRM helped to ensure one man one vote during the election $(\mathrm{M}=2.80, \mathrm{SD}=.81)$. However, subsequent results disagreed that the use of CRM made the process open and devoid of Electoral violence and intimidation $(M=1.91, S D=1.11)$, also, that electorates' confidence and optimism in the system that their votes will count has been restored $(M=1.93, S D=1.08)$, that with the $C R M$, results collated in the polling units cannot be changed in the collation center $(M=1.78, S D=.98)$, and, that the new CRM did prevent the falsification of the 2019 gubernatorial election results in Rivers State $(M=1.83, S D=1.00)$. These decisions are based on the Mean rating of 2.50 and above for accepting an item and Mean below 2.50 for rejecting the item. Therefore, with an overall mean of 2.21 and a standard deviation of .318, the result obtained from the questionnaire distributed shows that the INEC improved CRM did not enhance the credibility of the 2019 gubernatorial election in Rivers State.

\section{Findings}

In this paper, the following issues were discovered:

- Although the enhancement of the CRM made capturing and authentication of voters finger-prints faster and more successful, it did not make the 2019 gubernatorial election in River State credible. This is because some of the irregularities that previously characterized elections in the state were still actively invoked during the election.

- The paper found that the major challenges that hindered the effectiveness of the CRM were mostly external factors that are beyond the scope of the machine. First, the CRM was not given a fair trial; the election was characterized by the falsification of results, and the imaginary allocation of figures. In other words, the CRM was not even used due to violence and the hijack of electoral materials. Secondly, though results were announced, the election did not hold in several polling units.

- Finally, the paper found that armed thuggery, activities of cultists, military interference and other controversies made the CRM less effective

\section{Conclusion and Recommendations}

This paper argued that the INEC improved CRM did not enhance the credibility of the 2019 governorship election in Rivers State. However, it does identify some of the external conditions that incapacitated the functionality and efficiency of the machine to include disruption by armed groups including military personnel working for a politician, none usage of the device in some areas, and imaginary allocation of figures by desperate politicians, among others. The following recommendation was made:

- This study strongly recommended the adoption of an electronic voters' system where voters can log-in and vote at the comfort of their homes using bank verification number (BVN) and personal identification number (PIN), and for those that cannot do so can as well vote in an INEC designated area closer to them.

\section{References}

i. Agbalajobi, T. D \& Agunbiade, T. A. (2016). Electoral violence and women's participation in electoral processes: challenges and prospects for future elections in Nigeria. Unilag Sociological Review (USR), Vol. 12, (2), Pp 73 94

ii. Akindele, S. T. (2010). Intra and inter-party post-election crisis/feud management in a pluralistic democracy: An x-ray of the Nigerian political landscape. African Journal of Political Science and International Relations, Vol. 5(6), pp. 287-330

iii. Aleyomi, M. B. (2013). Intra-Party Conflicts in Nigeria: The Case Study of People's Democratic Party (PDP). Journal of Southern African Studies, Vol. 2 (4), pp. 130-146

iv. Ashindorbe. K (2018) Electoral Violence and the Challenge of Democratic Consolidation in Nigeria. India Quarterly, 74(1) 92-105

v. Atelhe, A. G. Lawal, A. M, and Terhile, A. (2019). Democracy, Intra-Party Struggle and Good Governance in Nigeria: The People's Democratic Party and all Progressive Congress Experience. European Journal of Scientific Research, Vol. 154 (4), pp. $491-498$

vi. EU (2019). Election Observation Mission NIGERIA 2019 Final Report .23 February? 9 and 23 March General Elections

vii. INEC (2019). Manual For Election Officials. Kas Arts Service Ltd, Onitsha Crescent

viii. IRI/NDI (2019) Nigeria International Election Observation Mission Final Report.

ix. Ituma (2017).The Effect of Card Readers on Election Credibility in Nigeria (A Case Study of 2015 Presidential Election). Middle-East Journal of Scientific Research, 25 (8): 1784-1792

x. Jega, A. (2011). Blames post-election violence on 'Crisis of Expectation'. Daily Trust online, Retrieved July 6, 2011.

xi. Kennedy and Patrick. (2009). How to combine multiple research options: Practical Triangulation (http://johnnyholland.org/2009/08/20/practical-triangulation)

xii. Krippendorff (1985). Communication From a Cybernetic Perspective. University of Pennsylvania

xiii. Niger Delta Watch (2019).A civil society report on the conduct of the Nigerian elections. Nigeria Civil Society Situation Room

xiv. Nigeria Civil Society Situation Room (2019). 2019 Elections: Smart Card Reader Challenges. Retrieved from www.placng.org/situation_room/sr/2019-elections-smart-card-reader-challenges/ 
xv. Nwafor, C (2019). Enhancement of the Accreditation System for Voting Process in Nigeria. Independent National Electoral Commission (INEC), Nigeria

xvi. Okechukwu (2019).Militarization, Electoral Violence and 2019 General Election in Nigeria. International Journal of Scientific and Research Publications, Volume 9, Issue 10

xvii. Olakunle O. Bamidele, R. Modupe, K. Oluwaseun, O. Magdalene, A. (2019), Trends In Electoral Violence In Nigeria. Journal of Social Sciences and Public Policy, Volume 11, (1), 223-242

xviii. Onapajo, H (2014), Violence and Votes in Nigeria: The Dominance of Incumbents in the Use of Violence to Rig Elections. Africa Spectrum, Vol. 49, (2), pp. 27-51

xix. Onebamhoi, O.N. (2011). Curbing Electoral Violence in Nigeria: The Imperative of Political Education. International Multidisciplinary Journal, Ethiopia Vol. 5 (5), Serial No. 22.Pp 99-110

xx. Onimisi, T, and Tinuola, O. L (2019) Appraisal of the 2019 Post-Electoral Violence in Nigeria Malaysian. Journal of Social Sciences and Humanities, Volume 4, (3) pp. 107 - 113

xxi. Onimisi, T, and Tinuola, O. L (2019) Appraisal of the 2019 Post-Electoral Violence in Nigeria Malaysian. Journal of Social Sciences and Humanities, Volume 4, (3) pp. 107 - 113

xxii. Shuaibu (2019).Investigating the Implementation of ICT Tool to Electoral Process in Nigeria. Journal of African Studies. Vol.6 No.1

xxiii. Uzodike and Onapajo (2019). Beyond the Card Reader: Anti-election Rigging Technology and National Security in Nigeria 